\title{
Studies on the Sclerotia of Some Species in The Genus Aspergillus
}

\author{
Soad M. Abu El-Souod, Omyma A. Awadalla, Susan M.W. Assawah, Y. A. \\ Mahmoud and Samah A.EL-Debaiky\# \\ Botany Department, Faculty of Science, Tanta University, Tanta, Egypt.
}

\begin{abstract}
T HIS study is part of a large study concerning with the sclerotia of some species of genus Aspergillus. In the present study, the sclerotia of different aspergilli (Aspergillus sclerotioniger, A. sclerotiorum, A. candidus, A. flavus, A. piperis, A. ochraceus, A. robustus, A. sepultus, A. petrakii, A. melleus, A. parasiticus and A. sclerotiicarbonarius) were examined concerning their morphological and anatomical characters. The mature sclerotia in the cultures of the used aspergilli appeared with different shapes (globose, sub-globose and oval). Transverse sections of mature sclerotia revealed two regions; the outer region, considered as rind, while the inner region proposed as medulla. These aspergilli were tested also by polymerase chain reaction (PCR) technique for the presence of sclerotium regulator (SclR) gene. The results indicated that eight of them contain this gene; these were A. petrakii, A. sepultus, A. robustus, A. sclerotiicarbonarius, A. melleus, A. sclerotioniger, A. parasiticus and A. sclerotiorum. These species exhibited bands with different molecular weights when tested for presence of SclR gene. Each Aspergillus species showed one band with specific molecular weight, these bands ranged in size; the highest was $436 \mathrm{bp}(A$. parasiticus) while the lowest was 134 bp (A. sclerotiicarbonarius).
\end{abstract}

Keywords: Aspergillus, Sclerotia, PCR and (SclR) gene.

\section{Introduction}

Some fungi are known to form sclerotia as a part of their life cycles. Sclerotia are defined as resting bodies which enable the fungus to survive and withstand environmental adverse conditions. These resting bodies could be produced by certain pathogenic and saprophytic fungal species such as those of some of the genera Claviceps, Sclerotinia, Sclerotium, Aspergillus, Penicillium, etc.

Sclerotia are resting bodies produced by many fungi as a mechanism for their long-term survival and propagation of the species Gloer et al. (1988) and Wicklow et al. (1988).

On the other hand, Calvo (2008) mentioned that sclerotia resemble cleistothecia in both their morphology and the genetic control of their development. This suggests that the two structures may be homologous but sclerotia being vestigial cleistothecia that lost the capacity to produce spores.
According to Georgiou et al. (2006), three substates in sclerotia biogenesis were distinguished:

(1) Sclerotial initial

Distinct initials formed from highly proliferating interwoven hyphae.

(2) Sclerotial development

The initials increase in size.

\section{(3) Sclerotial maturation}

Characterized by surface delimitation, internal consolidation, melanin pigmentation, and often associated with droplet excretion (exudate).

Aspergillus species are widespread in different environments and climates as saprophytes and parasites. Several aspergilli such as groups of $A$. niger (black aspergilli), A. flavus, A. ochraceus contain many species which produce sclerotia during their life cycles. 
Raper \& Thom (1949), Raper \& Fennell(1965) and Christensen (1981) reported that synnemata and sclerotia are important morphological characters for identifying some species of Aspergillus, Penicillium and related genera.

Bojovic-Cvetic \& Vujicic (1988) stated that the sclerotia of A. flavus are comprised of a rind and a sub-rind and central medullary cells. The rind is made of flattened cells with darkly-pigmented walls and empty lumina; sub- rind cells have partially pigmented walls and cytoplasm containing glycogen particles. The thick walled medullary cells contain mostly polysaccharides.

Moreover Samson et al. (2007) illustrated that A. sclerotioniger is able to produce sclerotia and give positive result with Ehrlish reagent at sclerotia regions which means that the sclerotia contain alkaloids.

Bacha et al. (2009) studied Aspergillus westerdijkiae which is the main producer of several biologically active polyketide metabolites including isoasperlactone and asperlactone. A 5298 bp polyketide synthase gene (aomsas) has been cloned in $A$. westerdijkiae by using gene walking approach and RACE-PCR. Moreover, Passone et al. (2010) quantified Aspergillus section Flavi population in peanuts using a real-time PCR system directed against the nor- 1 gene of the aflatoxin biosynthetic pathway.

Recently, many mycologists have stepped up their studies on the sclerotia of different species of genus Aspergillus where the aspergilli are distributed in diverse environments. This work was designed to study the sclerotia of (A. sclerotioniger, A. sclerotiorum, A. candidus, A. flavus, A. piperis, A. ochraceus, A. robustus, A. sepultus, A. petrakii, A. melleus, A. parasiticus and A. sclerotiicarbonarius) concerning their morphological and anatomical characters. These aspergillii were tested by PCR technique for the presence of SclR gene which encodes basic helix- loop-helix transcription factor which regulates the hyphal morphology and promotes sclerotial formation in Aspergillus oryzae.

\section{Materials and Methods}

\section{The tested fungi}

In the present study, sclerotia forming aspergilli were selected. Aspergillus sclerotioniger, A. sclerotiorum, A. candidus, A. flavus, A. piperis, A. ochraceus, A. robustus, A. sepultus, A. petrakii, A. melleus, A. parasiticus and A. sclerotiicarbonarius were purchased from the mycological center, Assiut University, Egypt and maintained on Czapek's medium (CZA), which was used for the growth of the selected species whenever needed.

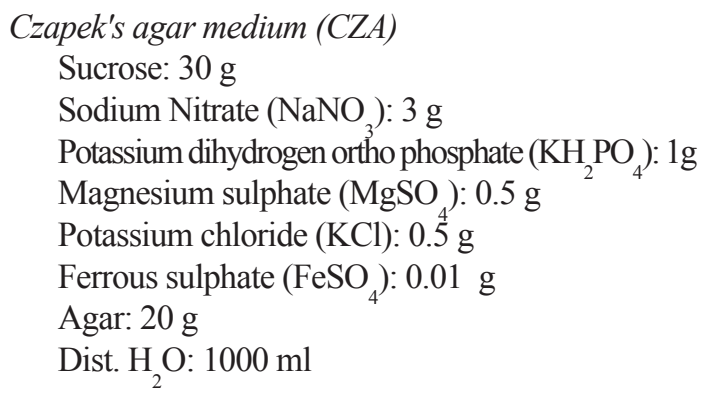

Morphology and anatomy of mature sclerotia of the tested aspergilli

This experiment was carried out using modified method adopted by Ryan et al. (2003). Mature sclerotia were gently picked from six days old cultures of A. flavus, A. melleus, A. ochraceus, A. robustus, A. sclerotiicarbonarius, A. sclerotioniger and A. sclerotiorum separately; however, these were collected from one month old culture of $A$. petrakii after which sclerotia were established. For $A$. candidus, A. parasiticus, A. piperis and A. sepultus sclerotial detection was achieved from 2 months old cultures, then could be harvested. The tested sclerotia were subsequently placed in a sieve and washed several times with distilled water to remove any remained attached mycelia, thereafter the sclerotia could be described morphologically.

For anatomical studies the method of Thakur et al. (1984) was conducted; thin transverse hand sections were established for the mature sclerotia, mounted in water, examined by light microscope and photographed.

Detection for the presence of SclR gene in different aspergilli using PCR analysis

Jin et al. (2011) examined the SclR gene which encodes basic helix-loop-helix transcription factor which regulates the hyphal morphology and promotes sclerotial formation in Aspergillus oryzae. In the present experiment, the presence of this gene in the different tested aspergilli was tested using PCR technique as follow:

\section{DNA extraction}

DNA was extracted and purified from the hyphae of bulked samples of the tested aspergilli separately using Gene JET Plant Genomic DNA purification 
minikit. This was adopted following the protocol of the manufacturer [Maxi Hot start PCR Master Mix $(2 \mathrm{X})]$.

\section{Optimization of PCR conditions}

According to Jin et al. (2011) the primer sequence of SclR gene is: QRT215-F (187): GAGAACTTCGCTCTCGATGTGC which is the forward strand and QRT215-R (311): CCGAAGTGATAGAACCGGCAT which is the Reverse strand.

Each isolated genomic DNA was used as template in the amplification reactions. A total of $12 \mu \mathrm{l}$ reaction mix was prepared. Amplification conditions were optimized using a gradient thermal cycler (Biometera Uno thermal cycler, Germany). After several experiments for optimizing the best conditions, a program for PCR was standardized with the following settings: Initial denaturation at $95^{\circ} \mathrm{C}$ for $4 \mathrm{~min}$, followed by 35 cycles of $1 \mathrm{~min}$ at $94^{\circ} \mathrm{C}$ for denaturation, annealing temperature according to each primer for $45 \mathrm{~s}$, and $2 \mathrm{~min}$ at $72^{\circ} \mathrm{C}$ for extension and a final extension of $5 \mathrm{~min}$ at $72^{\circ} \mathrm{C}$ and then temperature was set at $4^{\circ} \mathrm{C}$ till removal of PCR tubes within $12 \mathrm{~h}$.

\section{Separation of PCR amplification products}

The amplification products were separated by mixing $10 \mu \mathrm{l}$ of the PCR-products of each primer and $2 \mu \mathrm{l}$ of selected buffer then loading the mix into the agarose wells. Electrophoresis was made in 1.7 $\%$ agarose gel prepared in $0.5 \mathrm{X}$ TAE buffer at $70 \mathrm{~V}$ for $3 \mathrm{~h}$. The PCR fingerprinting was visualized using a Gel Works 1D advanced gel documentation system (UVP, UK) and photographed under UV light. The size of each band was estimated using 100 bp DNA ladder (Fermentas) as a standard marker.

To prepare the gel, $100 \mathrm{ml} 0.5 \mathrm{X}$ TE buffer were added to $1.7 \mathrm{~g}$ agarose and the mixture was heated in a microwave tell complete melting and left to cool to $60^{\circ} \mathrm{C}$ then ethidium bromide was added to the solution in a concentration of $0.2 \mu \mathrm{g} / \mathrm{ml}$.

\section{Results and Discussion}

Morphological studies of mature sclerotia of the tested aspergilli

Table 1 and Fig.1 illustrate the morphological characters (shape, color, size and compactness) of mature sclerotia of the tested aspergilli. The mature sclerotia in the cultures of the used aspergilli appeared with different shapes (globose, sub-globose and oval). The sclerotia of $A$. sepultus and A. melleus were too small to be recognized in the culture by naked eye so they were examined and photographed using microscope (Fig. 1: J\& K). The sclerotia of A. melleus, A. candidus and A. petrakii were globose (Fig. 1: K, F\& L respectively).

The color of sclerotia of $A$. melleus, A. candidus and $A$. petrakii were reddish brown, brown and brownish cinnamon respectively. The size of sclerotia of $A$. candidus and $A$. petrakii were medium in size; they measured $0.43 \times 0.43 \mathrm{~mm}$ and $0.62 \times 0.62 \mathrm{~mm}$ respectively. On the other hand, A. melleus sclerotia were too small to be only detected microscopically; measuring $0.3 \times 0.3 \mathrm{~mm}$.

These results mostly in accordance with Christensen, (1982) who reported that, A. melleus colonies on malt agar were characterized by production of yellow conidial heads and sclerotia were mostly of $0.350 .4-\mathrm{mm}$ diameter and creamy to golden color. However, Samson \& Mouchacca (1975) described the sclerotia of A. melleus on Czapek agar as hard, more or less globose, 0.1$0.2 \mathrm{~mm}$ in diameter, white at first, later yellow to brownish. Concerning sclerotia of $A$. petrakii our results discrepant that of Christensen (1982) who did not observe any sclerotia in $A$. petrakii. While Varga et al. (2007) described the sclerotia of $A$. candidus when produced at first take white color then quickly becoming reddish purple to black consisting of thick walled parenchyma like cells.

The present study revealed that sclerotia of $A$. piperis, A. sclerotiicarbonarius and A. sclerotioniger were globose to sub-globose (Fig. 1: B, C\& A, respectively). The colors of sclerotia of these species were found to be brownish red, black and light to dark brown with surface exudate droplets respectively. Sclerotia of $A$. sclerotioniger, A. sclerotiicarbonarius were medium in size; they measured $0.55 \times 0.59 \mathrm{~mm}$ to $0.73 \times 0.73 \mathrm{~mm}, 0.43 \times 0.57 \mathrm{~mm}$ respectively; but $A$. piperis sclerotia were larger $(1.14 \times 1.147$ $\mathrm{mm}$ to $1.53 \times 1.55 \mathrm{~mm}$ ). Many researchers studied sclerotia of black aspergilli; Samson et al. (2007) reported that the sclerotia of $A$. sclerotioniger and A. sclerotiicarbonarius were yellow to orange to red- brown while sclerotia of $A$. piperis were yellow to pink brown $(0.5-0.8 \mathrm{~mm})$. In the meantime, Noonim et al. (2008) stated that the sclerotia of $A$. sclerotiicarbonarius were produced abundantly in most isolates of this species, and were globose, sub globose to ellipsoidal with yellow to orange to redbrown color and diameter measuring 0.6 to $1.6 \mathrm{~mm}$. 


\begin{tabular}{|c|c|c|c|c|}
\hline$\frac{\pi}{3}$ & $\begin{array}{l}\text { : } \\
\frac{0}{0} \\
\frac{0}{0}\end{array}$ & 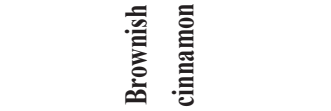 & $\stackrel{\Xi}{\circ}$ & 预 \\
\hline 彦 & $\begin{array}{l}\text { : } \\
\frac{0}{0} \\
\frac{0}{0}\end{array}$ & 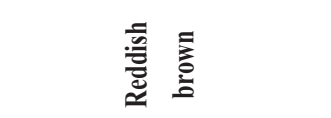 & $\begin{array}{l}\stackrel{m}{\grave{x}} \\
\stackrel{x}{a}\end{array}$ & 窇 \\
\hline 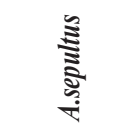 & 䔍 & 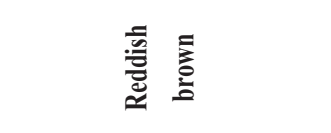 & 尝营 & 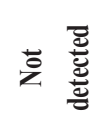 \\
\hline 善 & 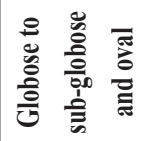 & 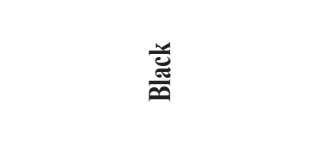 & 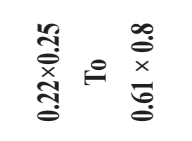 & 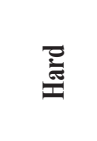 \\
\hline 竎 & 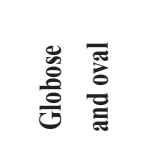 & 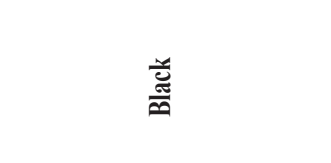 & 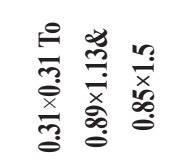 & 䔍 \\
\hline 离 & 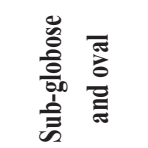 & 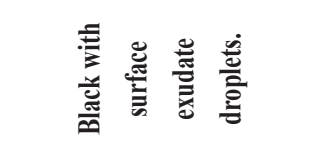 & 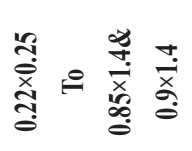 & 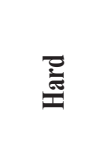 \\
\hline 宽 & $\frac{0}{0}$ & 言 & 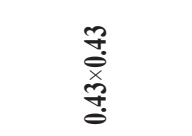 & 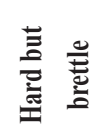 \\
\hline 总 & 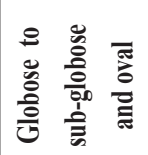 & 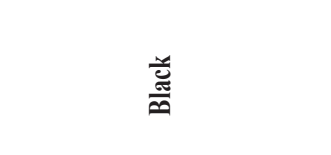 & 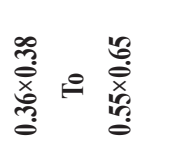 & 䒿 \\
\hline 童 & $\overline{\tilde{\sigma}}$ & 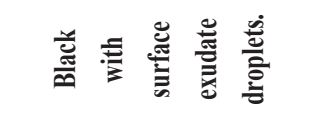 & 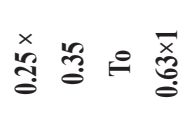 & 퐆 \\
\hline 竎言 & 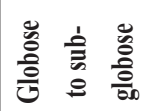 & 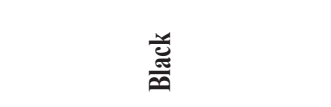 & $\stackrel{x}{\text { gf }}$ & 劲 \\
\hline 产 & 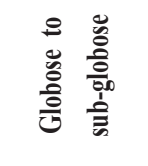 & 产 & 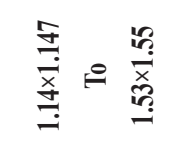 & 䒿 \\
\hline 竎 & 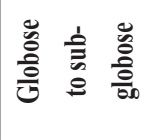 & 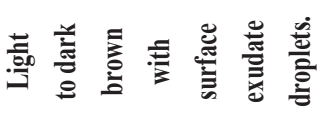 & 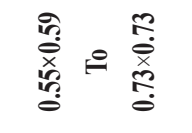 & 茎 \\
\hline 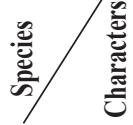 & 产 & $\frac{\grave{z}}{3}$ & 氞 & 槖 \\
\hline
\end{tabular}

Egypt. J.Bot. 57, No.2 (2017) 


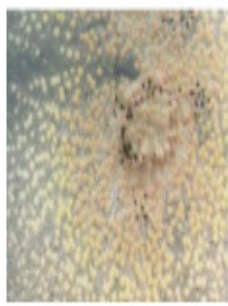

(A) A, sclerotioniger

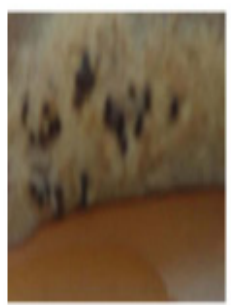

(F) A. candidus

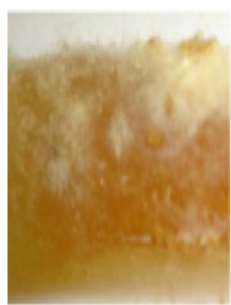

Culture

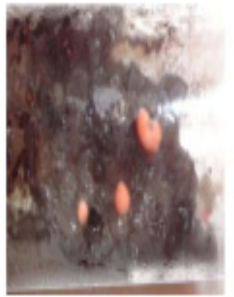

(B) A. piperis

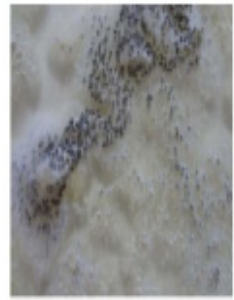

(G) A. ochraceus

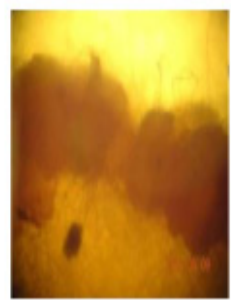

Under microscope

(J) A. sepulius

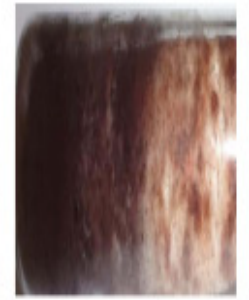

(c) A. sclerotiicarbonarius

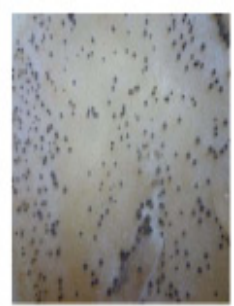

(H) A. sclerotiorum

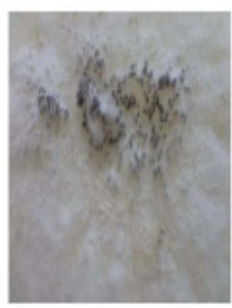

(D) A. flavus

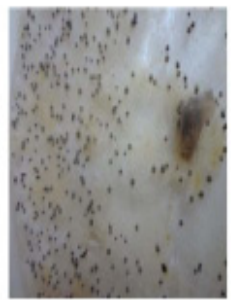

(I) A. robustus

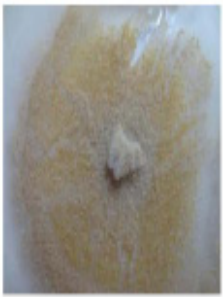

Culture

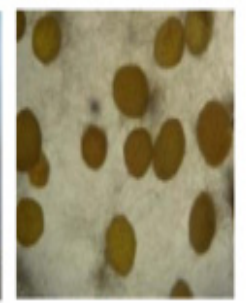

Under microscope

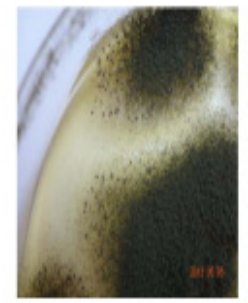

(E) A. parasiticus

(K) A. melleus

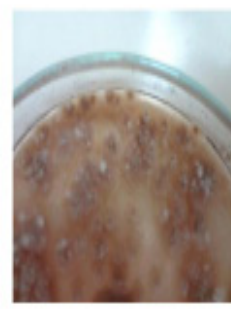

(L) A. petrakii

Fig.1. Appearence of mature sclerotia of tested aspergilli.

Sclerotia of $A$. parasiticus and A. robustus were globose to sub-globose to oval (Fig. 1: E\&I, respectively); sclerotia of $A$. flavus, A. ochraceus and $A$. sclerotiorum were oval, sub-globose to oval and globose to oval as illustrated in Fig.1: D, G\& H, respectively while sclerotia of $A$. sepultus were irregular in shape (Fig. 1: J). When the colors of sclerotia of $A$. flavus, A. parasiticus, A. ochraceus, A. robustus and $A$. sclerotiorum were examined they appeared to be black

A. flavus, A. ochraceus, A. parasiticus, A. robustus and $A$. sclerotiorum each exhibited different sizes of sclerotia. Of these smaller sizes measured $0.25 \times 0.35 \mathrm{~mm}, 0.22 \times 0.25 \mathrm{~mm}, 0.36 \times 0.38$ $\mathrm{mm}, 0.22 \times 0.25 \mathrm{~mm}$ and $0.31 \times 0.31 \mathrm{~mm}$, while larger sizes were oval and found to be $0.63 \times 1 \mathrm{~mm}, 0.9 \times 1.4$ $\mathrm{mm}, 0.55 \times 0.65 \mathrm{~mm}, 0.61 \times 0.8 \mathrm{~mm}$ and $0.85 \times 1.5 \mathrm{~mm}$, respectively.

Christensen (1982) stated that A. ochraceus sclerotia were produced in some strains, irregular in form, up to 1 - $2 \mathrm{~mm}$ diameter, lavender to vinaceous at maturity. The same auther documented that sclerotia of $A$. robustus are yellow-brown to black, irregular in form, $0.2500 .900-\mathrm{mm}$ in longest dimension; in the meantime, sclerotia of $A$. sclerotiorum were produced in some strains, pale, 1 - $1.5 \mathrm{~mm}$ diameter. Earlier Neill (1940) reported that some strains of $A$. ochraceus produce abundant sclerotia which while sclerotia of $A$. sclerotiorum are abundant, first appearing in cultures 3 days old, globose or sub-globose, white at first, soon becoming light cream and then flesh pink. Also, the same author reported that sclerotia produced by some strains of A. flavus at first appeared as white weft of fine aerial hyphae, later becoming globose, black, to $0.7 \mathrm{~mm}$ diameter, frequently aggregated into masses. Moreover, Cotty (1989) recorded that different isolates of A. flavus can be categorized either as the typical $\mathrm{L}$ strain with sclerotia $>0.4 \mathrm{~mm}$ in diameter or as the $\mathrm{S}$ strain which is dominated by abundant small sclerotia $<0.4 \mathrm{~mm}$ in diameter.

Horn et al. (2009) stated that sclerotia of Petromyces parasiticus (which is the sexual state of $A$. parasiticus) produced sclerotia and stromata similar in external appearance, globose to ellipsoidal, with size 
ranged from $0.25-0.3$ to $1.2-1.3 \mathrm{~mm}$, white in color becoming pink brown and finally dark brown to black; inner matrix was light to dark brown, consisting of pseudoparenchymatous tissue.

In the present study, sclerotia of $A$. sepultus were difficultly detected in the culture for their minute size and were difficult to be measured (Fig. 1: J). Tuthill \& Christensen, (1986) reported that sclerotia in this species were absent.

Anatomical studies of mature sclerotia of the tested aspergilli

Transverse sections of sclerotia of $A$. sclerotioniger, A. piperis, A. sclerotiicarbonarius,
A. candidus, A. melleus and A. petrakii revealed two regions; the outer region, considered as rind, was brownish and hard while the inner region proposed as medulla appeared as white pseudoparenchymatous tissue, (Fig.2: A, B, C, F, $\mathrm{K} \& \mathrm{~L}$ respectively). The mature sclerotia of $A$. melleus could not be recognized in the culture by naked eye but by reddish brown regions in the plate culture (Fig. 1: K). Microscopically these regions revealed globose to sub-globose sclerotia with reddish brown color.Anatomically two regions were clear; the outer region (rind) was reddish brown and the inner region (medulla) composed of colorless pseudoparenchymatous tissue (Fig. 2: K).
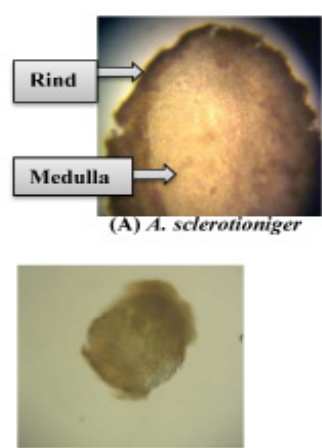

(F) A. candidus

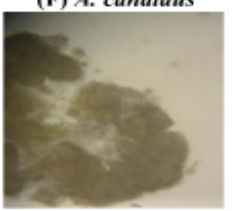

(K) A. melleus

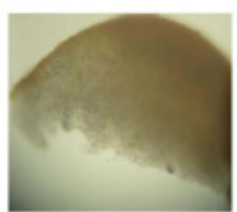

(B) A. piperis

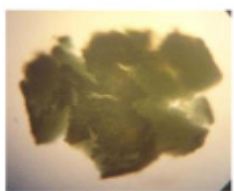

(G) A. ochraceus

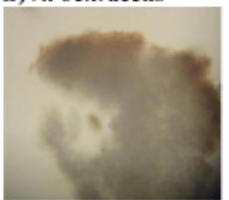

(L) A. petrakii

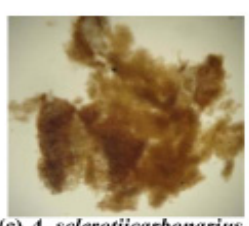

(c) A. sclerotiicarbonarius

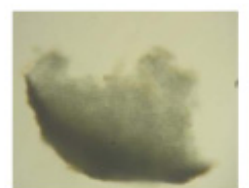

(H) A. sclerotiorum

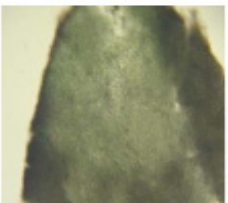

(D) A. flavus

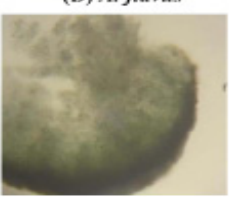

(I) A. robustus

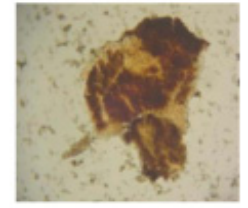

(E) A. parasiticus

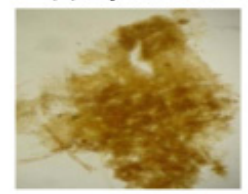

(J) A. sepultus

Fig.2. Anatomical features of mature sclerotia of the tested aspergilli.

On the other hand, the rinds of sclerotia in A. flavus, A. ochraceus, A. robustus and $A$. sclerotiorum were black while medullas of these species were composed of colourless pseudoparenchymatous tissues (Fig. 2: D, G, I \& $\mathrm{H}$, respectively). Under microscope the transverse section of sclerotia of $A$. parasiticus revealed dark brown rind and brownish yellow medulla, while the macerated sclerotium of $A$. sepultus appeared as woven mass of swollen tissues traversed by swollen hyphae (Fig. 2: J).

Detection of the presence of SclR gene in different used aspergilli by PCR analysis:

Formation of sclerotia in the genus Aspergillus was regulated by different genes. The present study dealing with the presence of only one gene (SclR gene) in the tested Aspergilli. Table 2 and Fig. 3 illustrate that eight of the tested aspergilli (A. petrakii, A. sepultus, $A$. robustus, A. sclerotiicarbonarius, $A$. melleus, $A$. sclerotioniger, A. parasiticus and A. sclerotiorum) exhibited bands with different molecular weights when tested for presence of SclR gene by the tested primer. Each Aspergillus species showed one band with specific molecular weight, these bands ranged in size; the highest was $436 \mathrm{bp}$ (A. parasiticus) while the lowest was 134 bp ( $A$. sclerotiicarbonarius). Jin et al. (2009) identified a novel bHLH protein encoding gene (SclR; AO090011000215) in A. oryzae by systematically deleting large chromosomal segments and further deletion analysis to screen a phenotype of dense conidia. Also, they mentioned that $A$. oryzae SclR shares high similarity with those 
of putative proteins from genome sequencing projects of $A$. niger, A. fumigatus and $A$. nidulans. The gene-disrupted strain was found to produce dense conidia, but sparse sclerotia, relative to the parent strain, suggesting that it possibly plays an important role in morphology and growth.

TABLE 2. Molecular weights of ScIR gene in the tested aspergilli

\begin{tabular}{lc}
\hline Aspergillus & $\begin{array}{c}\text { Molecular size of SclR gene } \\
\text { (bp) }\end{array}$ \\
\hline A. petrakii & 259 \\
A. sepultus & 232 \\
A. robustus & 226 \\
A. sclerotiicarbonarius & 134 \\
A.piperis & - \\
A. melleus & 273 \\
A. sclerotioniger & 387 \\
A.candidus & - \\
A. parasiticus & 436 \\
A.flavus & - \\
A.ochraceus & - \\
A. sclerotiorum & 414 \\
\hline
\end{tabular}

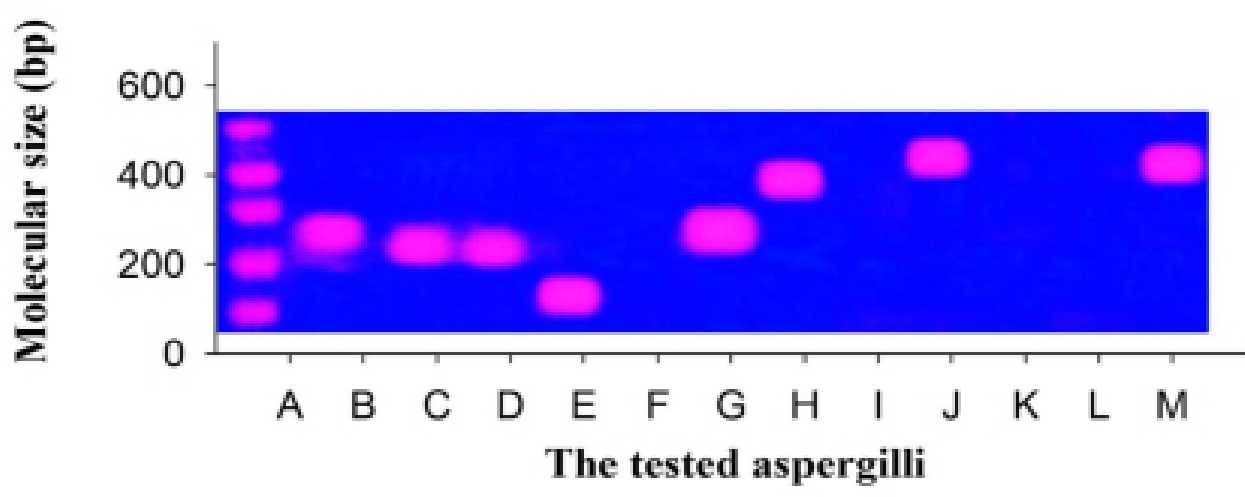
A: Marker
$\mathrm{G}:$ A. melleus
B: A. petrakii
$\mathrm{H}$ : A. sclerotioniger
C: A. sepultus
I: A. candidus
D: A. robustus
$\mathrm{J}:$ A. parasiticus
E: A. sclerotilcarbonarius
$\mathrm{K}$ : A. flavus
F: A. piperis
L: A. ochraceus
$\mathrm{M}$ : A. sclerotionm

Fig. 3. Bands on agarose gel indicating the presence of ScIR gene in 8 species of tested aspergilli with different molecular weights. 
Furthermore Jin et al. (2011) reported the characterization of the SclR gene, along with analysis of its function in $A$. oryzae. Overexpression of the SclR gene led to abnormal hyphal morphology and sclerotial formation.

In related work Chang (2008) found that the deletion of a zinc finger calcineurin response gene, crzA, in $A$. parasiticus resulted in the production of mainly immature sclerotia.

Moreover Kale et al. (2008) examined the role of nuclear regulator (LaeA) in two mutants and wild type of $A$. flavus and found that LaeA had a major effect on A. flavus secondary metabolism where $\Delta l a e A$ and over-expression lae $A$ strains yielded opposite phenotypes resulting in changes in secondary metabolite production. The two mutant strains also exhibited striking morphological phenotypes in the loss (increase) of sclerotial production in comparison to wild type. Transcriptional examination of the mutants showed LaeA negatively regulates expression of its recently identified nuclear partner VeA (another global regulator of secondary metabolites and sclerotia of $A$. flavus).

\section{Conclusion}

From the present study, it could be concluded that:

1. The mature sclerotia of the tested Aspergilli were markedly varied in shape, color, size, compactness and anatomical features.

2. The $S c l R$ gene was detected using PCR and was found with different molecular weights in eight species from the tested Aspergilli.

\section{References}

Bacha, N., Dao, H.P., Atoui, A., Mathieu, F., O'Callaghan, J., Puel, O., Liboz, T., Dobson, A.D.W. and Ahmed Lebrihi, A. (2009) Cloning and characterization of novel methylsalicylic acid synthase gene involved in the biosynthesis of isoasperlactone and asperlactone in Aspergillus westerdijkiae. Fungal Genetics and Biology, 46, 742-749.

Bojovic-Cvetic, D. and Vujicic, R. (1988) Polysaccharide cytochemistry in maturing Aspergillus flavus sclerotia. Trans. Br. Mycol. Soc. (91), 619 - 624.

Calvo, A. (2008) The VeA regulatory system and its role in morphological and chemical development in fungi. Fungal genetics and biology: $F G \& B, 45$ (7), 1053-1061.
Chang, P.K. (2008) Aspergillus parasiticus crzA, which encodes calcineurin response zinc-finger protein, is required for aflatoxin production under calcium stress. Int. J. Mol. Sci. 9, 2027-2043.

Christensen, M. (1981)A synoptic key and evaluation of species in the Aspergillus flavus group. Mycologia, (73), 1056 -1084.

Christensen, M. (1982) The Aspergillus ochraceus group: two new species from western soils and a synoptic key. Mycologia, 74 (2), 210225 -

Cotty, P. J. (1989) Virulence and cultural characteristics of two Aspergillus flavus strains pathogenic on cotton. Phytopathology, 79, 808-814.

Georgiou, D.C., Patsoukis, N., Papapostolou, I. and Zervoudakis, G. (2006) Sclerotial metamorphosis in filamentous fungi is induced by oxidative stress. Integr. Compar. Biol. 46, 691712-.

Gloer, J.B., TePaske, M.R., Sima, J.S., Wicklow, D.T. and Dowd, P.F. (1988) Antiinsectan aflavinine derivatives from the sclerotia of Aspergillus flavus. J. Org. Chem. 53, 5457- 5460.

Horn, B.W., Ramirez-Prado, J.H. and Carbone, I. (2009) The sexual state of Aspergillus parasiticus. Mycologia, 101 (2), 275 -280.

Jin, F. J., Takahashi, T., Machida, M. and Koyama, Y. (2009)Identification of a basic helix-loophelix-type transcription regulator gene in Aspergillus oryzae by systematically deleting large chromosomal segments. Applied and Environmental Microbiology, 75,5943-5951.

Jin, F.J., Takahashi, T., Matsushima, K., Hara, S., Shinohara, Y., Maruyama, J., Kitamoto, K. and Koyama, Y. (2011) SclR, a Basic Helix-LoopHelix Transcription Factor, Regulates Hyphal Morphology and Promotes Sclerotial Formation in Aspergillus oryzae. Eukaryotic Cell, 10 (7), 945- 955.

Kale, S.P., Milde, L., Trapp, M.K., Frisvad, J.C., Keller, N.P. and Bok, J.W. (2008) Requirement of LaeA for secondary metabolism and sclerotial production in Aspergillus flavus. Fungal Genetics and Biology, 45, 1422-1429.

Neill, J.C. (1940) The mould fungi of New Zealand. II.The genus Aspergillus. Noonim P, Mahakarnchanakul W, Varga J, Frisvad JC, Samson RA(2008).Two novel species of Aspergillus section Nigri from Thai coffee beans. International Journal of Systematic and Evolutionary Microbiology, 58, 1727-1734. 
Noonim, P., Mahakarnchanakul, W., Varga, J., Frisvad, J.C. and Samson, R.A. (2008) Two novel species of Aspergillus section Nigri from Thai coffee beans. International Journal of Systematic and Evolutionary Microbiology, 58, 1727- 1734.

Passone, M.A., Rosso, L.C., Ciancio, A. and Etcheverry, M. (2010) Detection and quantification of Aspergillus section Flavi spp. in stored peanuts by real- time PCR of nor-1 gene, and effects of storage conditions on aflatoxin production. International Journal of Food Microbiology, 138, 276-281.

Raper, K.B. and Fennell, D.I. (1965). The genus Aspergillus."Baltimore: Williams and Wilkins: p.34.

Raper, K.B., Thom, C. (1949) "A Manual of The Penicillia." Baltimore: Williams and Wilkins. 875 P.

Ryan, S., Schnitzhofer, W., Tzanov, T., CavacoPaulo, A. and Gübitz, G.M. (2003)An acid-stable laccase from Sclerotium rolfsii with potential for wool dye decolourization. Enzyme and Microbial Technology, 33,766-774.

Samson, R.A. and Mouchacca, J. (1975)Additional notes on species of Aspergillus, Eurotium and
Emericella from Egyptian desert soil. Antonie van Leeuwenhoek, (41), 343 -351.

Samson, R.A., Noonim, P., Meijer, M., Houbraken, J., Frisvad, J.C. and Varga, J. (2007) Diagnostic tools to identify black aspergilli. Studies in Mycology, 59 (1), 129 -145.

Thakur, R.P., Rao, V.P. and Williams, R.J. (1984) The morphology and disease cycle of ergot caused by Claviceps fusiformis in pearl Millet. The American Phytopathological Society, 74 (2), $201-205$.

Tuthill, D.E. and Christensen, M. (1986) Aspergillus sepultus, a new species in the Aspergillus ochraceus group. Mycologia, 78 (3), 475 -477.

Varga, J., Frisvad, J.C. and Samson, R.A. (2007) Polyphasic taxonomy of Aspergillus section Candidi based on molecular morphological and physiological data. Studies in Mycology, 59, 75-88.

Wicklow, D.T., Dowd, P.F., TePaske, M.R. and Gloer, J.B. (1988)Sclerotial metabolites of Aspergillus flavus toxic to a deteritivorous maize insect (Carpophilus hemipterus, Nititulidae). Trans. Br. Mycol. Soc. 91 (3), 433- 438.

Received: 23/3/2017

Accepted: 4 / 5/ 2017 
دراسات على الأجسام الحجرية لبعض أنواع الجنس اسبرجيلس

سعاد محمد أبو السعود،أميمة أحمد عوض الله، سوزان محمد وجدى السواح، يحيى عبد الجليل محمود و

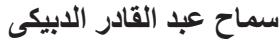

قسم النبات ـ كلية العلوم - جامعة طنطا لـإيكا ـ طنطا - مصر.

يهدف هذا البحث إلى در اسة الأجسام الحجرية لبعض أنواع جنس الاسبرجيلس وذلك من ناحية الثكل الظاهرى

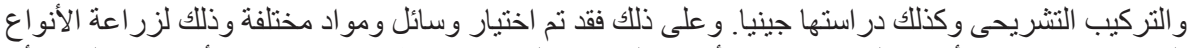

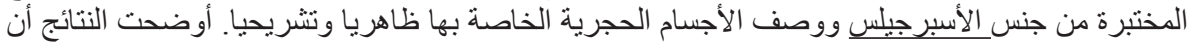

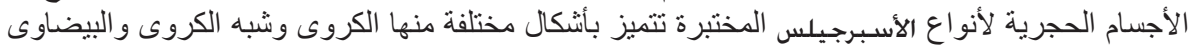

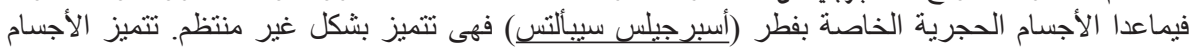

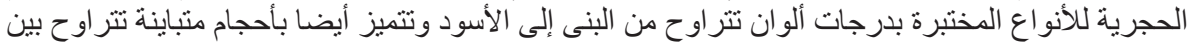

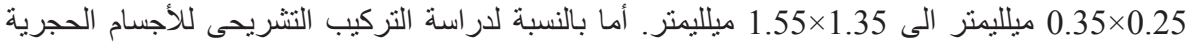

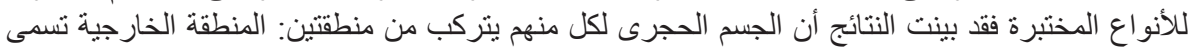
و الداخلية تسمى (Rind) أسبرجيللس سيبألتس فأنه يتكون من كتلة متداخلة من الأنسجة يعتر فئها بعض الأن الخيوط المنتفخة.

كما استهدفت الدراسة الحالية أيضا تحديد وجود جين (SclR) في خلايا خيوط أنواع الأسـبرجيلس

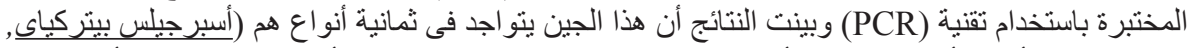

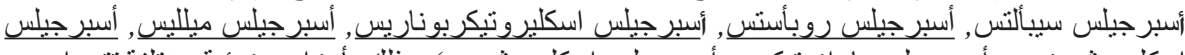

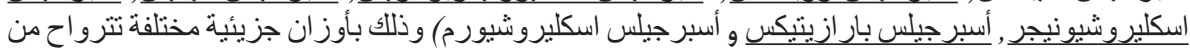
في النوع أسبرجيلس اسكيروتيايكربوناريس إلى bp 436 bp فئس أسبر جيلس بار ازيتيكس. 